\title{
PENGARUH PENJUALAN SUKU CADANG ALAT BERAT TERHADAP PENINGKATAN PENDAPATAN PADA PT. TRAKTOR NUSANTARA CABANG MAKASSAR
}

\author{
Maryadi \\ Dosen STIE Nobel, Makassar
}

\begin{abstract}
ABSTRAK
Penelitian ini bertujuan untuk mengetahui pengaruh penjualan suku cadang alat berat terhadap peningkatan pendapatan. Lokasi penelitian ini dilakukan di Perusahaan PT Traktor Nusantara Cabang Makassar yang berlokasi di jalan Sultan Alaudiddin Makassar. Adapun metode pengumpulan data digunakan yaitu metode kepustakaan dan metode lapangan. Sumber data dalam penelitian ini pada dasarnya menggunakan dua jenis data yaitu; data primer dan data sekunder. Teknik analisis data yang digunakan adalah analisis regresi linier berganda. Hasil penelitian menunjukkan bahwa penjualan tunai suku cadang alat berat berpengaruh signifikan terhadap peningkatan pendapatan PT. Traktor Nusantara cabang makassar tetapi tidak signifikan. Hal ini dapat di buktikan dari nilai signifikan uji t pada penjualan tunai 0,034 lebih besar di banding 0,05 $(0,034<0,05)$ maka Ho ditolak berarti variabel bebas yang diuji secara nyata berpengaruh signifikan terhadap variabel terikat.
\end{abstract}

Kata Kunci: Penjualan, Suku Cadang, Peningkatan Pendapatan.

\section{PENDAHULUAN}

Pada umumnya tujuan suatu perusahaan ditinjau dari sudut pandang ekonomi adalah untuk memperoleh keuntungan (profit oriented), menjaga kelangsungan hidup dan kesinambungan operasi perusahaan, sehingga mampu berkembang menjadi perusahaan yang besar dan tangguh. Kesuksesan perusahaan dalam bisnis hanya bisa dicapai melalui pengelolaan yang baik, khususnya pengelolaan manajemen keuangan sehingga modal yang dimiliki bisa berfungsi sebagaimana mestinya. Penjualan barang ataupun jasa merupakan sumber pendapatan perusahaan. Dalam melaksanakan penjualan kepada para konsumen, perusahaan dapat melakukannya secara tunai ataupun secara kredit. Perusahaan akan lebih menyukai transaksi penjualan yang dapat dilakukan secara tunai, karena perusahaan akan segera menerima kas dan kas tersebut dapat segera digunakan kembali untuk mendapatkan pendapatan selanjutnya. Di pihak lain, para konsumen umumnya lebih menyukai bila perusahaan dapat melakukan penjualan secara kredit, karena pembayaran dapat ditunda. Dalam kenyataannya, penjualan kredit pada kebanyakan perusahaan biasanya jauh lebih besar dari penjualan tunai. Dari penjualan kredit tersebut maka akan timbul akun piutang (Account Receivable). 
84|Ad'ministrare, Vol. 3 No. 2, 2016

Penjualan adalah jumlah yang dibebankan kepada pelanggan untuk barang dagang yang dijual, baik tunai maupun kredit. Penjualan kredit adalah penjualan barang dagangan dengan kesepakatan antara pembeli dan penjual pada saat transaksi yaitu pembayaran akan dilakukan pada waktu yang akan datang. Dalam perusahaan yang bergerak di bidang Industri dan Distributor suku cadang alat-alat berat. Fokus utama perusahaan adalah melakukan penjualan secara kredit dan non kredit. Penjualan kredit tidak akan segera menghasilkan penerimaan kas. Tapi menimbulkan akun piutang kepada konsumen, atau yang biasa disebut dengan piutang usaha, dan barulah kemudian pada hari jatuh temponya, terjadi aliran kas masuk (cash flow) yang berasal dari pengumpulan piutang usaha tersebut.

Piutang usaha/dagang (Account Receivable) yaitu Transaksi yang paling banyak memungkinkan menciptakan piuatang adalah penjualan barang secara kredit. Piutang usaha ini normalnya akan tertagih dalam periode waktu yang relatif pendek, seperti 30-60 hari yang akan dikelompokkan menjadi asset lancar. Piutang usaha/dagang (Account Receivable) adalah hak atau tagihan kepada pihak lainnya yang nantinya akan dimintai pembayarannya jika sudah waktunya. Tidak ada satupun perusahaan yang mengharapkan sebagian kredit yang dikeluarkan tidak bisa dibayar oleh debitur walaupun dalam proses pemberian kredit telah diteliti sebaikbaiknya. Namun, pada kenyataannya resiko tak tertagih atas sejumlah piutang pasti akan ditemui. Untuk mencegah terjadinya penumpukan modal kerja pada kredit tersebut diperlukan suatu sistem akuntansi yang baik dalam pencatatan dan pengelolaan kredit. Pengakuan, penilaian, penyisihan dan penghapusan kredit/piutang merupakan seperangkat sistem akuntansi yang harus dijalankan sesuai dengan prosedur untuk mencapai tujuan tersebut.

PT Traktor Nusantara bersama-sama dengan anak perusahaannya, PT Swadaya Harapan Nusantara, secara berkesinambungan mengembangkan bisnisnya, yaitu Distribusi, Penyewaan Dan Kontrak, Layanan Purna Jual, Dan Peralatan Bekas, untuk keperluan Industri, Pertanian, Penggerak dan Energi serta Konstruksi Jalan. Transaksi di PT Traktor Nusantara secara umum dapat dibagi menjadi dua bagian, yaitu transaksi Sales unit dan transaksi After sales atau product support. Transaksi sales unit yaitu saat pembelian main product PT Traktor Nusantara yaitu berupa alat-alat berat. Pada saat transaksi ini biasanya pembayaran dilakukan secara tunai dan tidak diperkenankan untuk pembayaran secara kredit. Transaksi After Sales atau Product Support adalah berupa penjualan suku cadang dari alat berat dan jasa perawatan maupun perbaikan alat berat. Untuk transaksi ini, biasanya dilakukan pembayaran secara tunai untuk pelanggan yang baru pertama kali melakukan transaksi, dan dapat dilakukan pembayaran secara kredit apabilah pelanggan tersebut telah sering melakukan transaksi sesuai kebijakan perusahaan. Jangka waktu kredit yang diberikan biasanya berkisar antara 30 hari sampai 45 hari. Dengan adanya kebijakan pemberian jasa secara kredit kepada pelanggan, PT. Traktor Nusantara Cab Makassar memiliki resiko sebagian dari penjualan kredit tidak akan tertagih atau bahkan kredit macet. Kredit yang tidak tertagih ini bisa disebabkan oleh beberapa faktor, seperti faktor kelengkapan dokumen tagihan, faktor keuangan pelanggan, dan beberapa faktor lainnya.

Kemudian dalam melakukan aktivitas penagihan kredit kepada customer, dapat pula dilakukan oleh sales Spare Part, ADH (Administration Dept Head) dan PDH (Part Dept Head) ini bertanggung jawab memantau pembayaran angsuran customer. Dalam Penagihan piutang 
usaha yang dilakukan oleh Sales Spare part, ADH dan PDH kepada customer untuk membayar utang kepada perusahaan.

Dalam sistem penjualan kredit yang ada dalam perusahaan dirancang untuk menangani transaksi penjualan kredit atas suatu produk yang dihasilkan. Dalam sistem ini, dilakukan pemisahan fungsi untuk setiap transaksi penjualan kredit, seperti pemisahan fungsi penjualan terpisah dari fungsi kredit dan fungsi penjualan terpisah dari fungsi gudang. Hal ini dimaksudkan untuk mencegah terjadinya kecurangan-kecurangan dalam pencatatan atas penjualan kredit seperti kecurangan pencatatan kuantitas yang dijual dalam faktur penjualan. Dengan adanya pemisahan fungsi tersebut, maka kedua fungsi akan saling mengecek dari pembukuan atas transaksi penjualan kredit dan untuk menghindari kecurangan dalam pengeluaran jumlah barang, atas barang yang dijual dengan barang yang dikeluarkan oleh gudang. Karena penjualan merupakan hal yang sangat penting mengingat tujuan utama dari perusahaan adalah memperoleh keuntungan. Kerugian yang timbul dari piutang tak tertagih/ kredit ini diakui sebagai kerugian piutang.

Kerugian piutang akan sangat berpengaruh pada laba operasional perusahaan. Dimana semakin besar biaya yang disisihkan untuk kerugian piutang tidak tertagih maka semakin sedikit laba operasional yang didapatkan sementara ekspektasi perusahaan adalah mencari laba sebanyak-banyaknya. Karena dipandang dari berbagai macam aspek, laba yang tinggi akan memberikan keuntungan yang besar untuk perusahaan, pemegang saham dan para pegawainya. Selain itu, Kegiatan perusahaan yang menghasilkan barang sesuai dengan bidang perusahaannya masing-masing adalah banyaknya kredit yang ditawarkan oleh perusahan lebih memperhatikan kredit, sehingga di butuhkan upaya inovatif yang berkesinambungan sehingga perusahaan mampu mencapai competitive advantage dan comperave advantage (berdaya saing tinggi) dalam jangka panjang. Bentuk salah satu cara atau teknik pencapaian tujuan tersebut adalah memperbesar omset penjualan yaitu dengan melakukan penjualan secara kredit. Tujuan dari penjualan kredit tersebut adalah memberikan keringanan kepada calon pelanggan untuk mendapatkan barang atau jasa yang ditawarkan oleh perusahaan dengan melakukan penjualan secara kredit.

\section{KAJIAN TEORI}

\section{Manajemen Keuangan}

Menurut Eugene (2001:6) manajemen keuangan merupakan bidang yang terluas dari tiga bidang keuangan, dan memiliki kesempatan karir yang sangat luas. Manajemen keuangan sangat penting bagi semua jenis perusahaan,termasuk bank dan lembaga keuangan lainnya, serta perusahaan industri dan ritel. Manajemen keuangan juga penting dalam kegiatan pemerintah, mulai dari sekolah, rumah, hingga departemen jalan tol. Manajer keuangan juga bertanggung jawab dalam memutuskan jangka waktu kredit bagi konsumen, berapa banyak kas dan persediaan yang harus disimpan, apakah untuk mengakuisisi perusahaan lainnya (Analisis Marger), dan berapa besarnya laba ditahan serta dividen yang harus di bayarkan perusahaan.

Eugene et.al (2001:7) berpendapat bahwa ketika manajemen keuangan berdiri sebagai bidang studi yang terpisah pada awal tahun 1990-an, penekanannya diberika pada aspek hukum 
86|Ad'ministrare, Vol. 3 No. 2, 2016

marger, pembentukan perusahaan baru,dan berbagai jenis sekuritas yang dapat diterbitkanperusahaan untuk menambah modal. Selama masa depresi pada tahun 1930-an, penekanannya beralih ke masalah sperti kebangkurutan dan reorganisasi, likuiditas perusahaan, dan requlasi pasar modal.

\section{Kredit}

Menurut Mulyono (2007:10) kredit adalah suatu penyerahan uang atau tagihan yang dapat dipersamakan dengan itu, berdasarkan persatuan atau kesepakatan pinjam untuk melunasi utangnya setelah jangka waktu tertentu dengan bunga jumlah imbalan atau pembagian hasil keuntungan. Suhardjono (2003:11) kredit adalah penyediaan uang atau yang disamakan dengan itu berdasarkan persetujuan pinjam meminjam antara bank lain pihak dalam hal mana pihak peminjam berkewajiban untuk melunasi hutangnya setelah jangka waktu tertentu dengan jumlah bunga yang telah ditentukan. Ahmad (2004:15) berpendapat bahwa kredit adalah kemampuan yang dilakukan suatu pembelian atau suatu pinjaman dengan suatu janji pembayarannya akan dilakukan, ditangguhkan pada suatu jangka waktu yang disepakati. Ensiklopedia umum (2000:17) kredit adalah sistem keuangan untuk memudahkan pemindahan modal dari pemilik kepada pemakai dengan pengharapan memperoleh keuntungan kredit diberikan berdasarkan kepercayaan orang yang diberikan terhadap kecakapan dan kejujuran si peminjam.

\section{Konsep Penjualan}

Secara umum penjualan adalah kegiatan tukar menukar yang dilakukan oleh pembeli dan penjual. Biasanya penjual menyerahkan barang atau jasa dan setelah diadakan kesepakatan harga, pembeli telah menerima dengan terlebih dahulu mengeluarkan jumlah uang. Penjualan menurut undang-undang umum hanya terbatas bagaimana suatu perusahaan dapat mengadakan pertukaran barang atau jasa sebanyak mungkin, yang diajukan untuk dijual secara menguntungkan tanpa memperhatikan kepentingan konsumen.

Menurut Kartajaya (2005:68) berpendapat bahwa penjualan adalah bagaimana menciptakan hubungan jangka panjang dengan pelanggan melalui produk atau jasa dari sebuah perusahaan.

Marom (2002: 28) Penjualan adalah penjualan barang dagangan sebagai usaha pokok perusahaan dan biasanya dilakukan secara teratur. Menurut Fess e al (2008:22) berpendapat bahwa penjualan adalah jumlah yang dibebankan kepada pelanggan untuk barang dagang yang dijual, baik tunai maupum kredit.

\section{Manajemen Penjualan}

Manajemen penjualan adalah aktifitas-aktifitas yang diperlukan untuk memimpin, mengarahkan dan mengawasi setiap proses penjualan yang dilakukan setiap individu penjual dalam organisasi. Dengan demikian manajemen penjualan kegiatan yang dilakukan sales manager dalam mengatur sales Peoplel. Kegiatan tersebut menyangkut menentukan tujuan atau goals dalam mission statement, menentukan strategi penjualan, menentukan tujuan-tujuan jangka pendek atau objectivues. 


\section{Jenis-jenis Penjualan}

a. Penjualan Tunai

Mulyadi (2000:455) berpendapat bahwa penjualan tunai dilaksanakan oleh perusahaan dengan cara mewajibkan pembeli melakukan pembayaran harga barang diserahkan oleh perusahaan kepada pembeli.Transaksi penjualan tunai dikatakan telah terlaksana apabila perusahaan telah menerima pembayaran dari pelanggan atas barang ataupun jasa yang kemudian akan diserahkan oleh perusahaan kepada pelanggan. Penjualan dilakukan oleh perusahaan dengan cara mewajibkan pembeli melakukan pembayaran harga barang terlebih dahulu sebelum barang diserahkan oleh perusahaan kepada pembeli. Setelah uang diterima oleh perusahaan barang kemudian diberikan kepada pembeli dan tranksaksi penjualan kemudian dicatat oleh perusahaan.

b. Penjualan Kredit

Mulyadi (2001:220) penjualan kredit dilaksanakan oleh perusahaan dengan cara mengirimkan barang sesuai dengan order yang diterima dari pembeli dan untuk jangka waktu tertentu perusahaan mempunyai tagihan kepada pembeli tersebut. Penjualan kredit yaitu transaksi penjualan yang dilakukan tetapi pembayarannya menggunakan jangka waktu tertentu sesuai kesepakatan bersama.

2. Faktor-faktor yang mempengaruhi penjualan kredit menurut Riyanto; 1990: 79)

a. Laba yang dihasilkan; penjualan kredit hendaknya mempunyai prosentase laba yang lebih tinggi jika dibanding penjualan tunai.

b. Perangkat kredit; penjualan kredit memerlukan perangkat kredit yang berupa faktur sebagai tanda bukti.

c. Pertimbangan hukum dalam pemberian kredit; dalam memberikan kredit perusahaan harus meninjau kebijaksanaan yang diambil agar sesuai dengan aspek hukum / ketentuan yang berlaku.

3. Keunggulan dan Kelemahan penjualan secara kredit:

a. Keunggulan:

1) Volume penjualan yang dilakukan perusahaan relatif tinggi.

2) Laba yang didapatkan perusahaan menjadi naik.

3) Keuntungan perusahaan diperoleh dari harga perunit ditambah dengan pendapatan bunga.

4) Nilai barang menjadi lebih tinggi.

b. Kelemahan penjualan secara kredit :

1) Adanya resiko kredit macet.

2) Bed debt yang tinggi.

3) Biaya yang ditimbulkan semakin tinggi. 
88|Ad'ministrare, Vol. 3 No. 2, 2016

4) Persediaan kas berkurang sehingga sulit mendapatkan Fresh Money

\section{Pendapatan}

Deddi (2009:179) berpendapat bahwa pendapatan didefinisikan sebagai penjualan barang dan penyerahan jasa, serta diukur dengan pembebanan yang dikenakan kepada pelanggan, klien, atau penyewa untuk barang jasa yang disediakan bagi mereka. Menurut Kieso, et.al (2007:516) berpendapat pengertian pendapatan adalah arus masuk aktiva dan atau penyelasaian kewajiban akibat penyerahan atau produksi barang, pemberian jasa atau kegiatan menghasilkan laba lainnya yang membentuk operasi utama atau inti perusahaan yang berkelanjutan selama suatu periode.

\section{Hipotesis}

Berdasarkan latar belakang dan rumusan masalah, maka penulis mencoba merumuskan hipotesis yang merupakan kesimpulan sementara dari penilitian sebagai berikut: Diduga bahwa penjualan tunai suku cadang alat berat berpengaruh signifikan terhadap peningkatan pendapatan pada PT. Traktor Nusantara Cabang Makassar.

\section{METODE PENELITIAN}

Lokasi penelitian ini dilakukan di Perusahaan PT Traktor Nusantara Cabang Makassar yang berlokasi di jalan Sultan Alaudiddin Makassar. Adapun metode pengumpulan data digunakan yaitu metode kepustakaan dan metode lapangan. Sumber data dalam penelitian ini pada dasarnya menggunakan dua jenis data yaitu; data primer dan data sekunder. Teknik analisis data yang digunakan adalah analisis regresi linier berganda. Adapun fokus dalam penelitian ini diarahkan untuk mengetahui; 1) Penjualan tunai (X1) yaitu, dilaksanakan oleh perusahaan dengan cara mewajibkan pembeli melakukan pembayaran harga barang diserahkan oleh perusahaan kepada pembeli. 2) Penjualan kredit (X2) yaitu, transaksi penjualan yang dilakukan tetapi pembayarannya menggunakan jangka waktu tertentu sesuai kesepakatan bersama. 3) Tinkat pendapatan (Y) yaitu, sebagai penjualan barang dan penyerahan jasa, serta diukur dengan pembebanan yang dikenakan kepada pelanggan, klien, atau penyewa untuk barang jasa yang disediakan bagi mereka. 


\section{HASIL DAN PEMBAHASAN}

Penjualan tunai suku cadang alat berat berpengaruh signifikan terhadap peningkatan pendapatan pada PT. Traktor Nusantara Cabang Makassar.

Tabel 1 Hasil Penjualan tunai, Penjualan Kredit dan Tingkat Pendapatan Pendapatan selama 6 tahun

\begin{tabular}{|c|c|c|r|}
\hline Tahun & $\begin{array}{c}\text { Penjualan Tunai } \\
(\mathbf{X 1})\end{array}$ & $\begin{array}{c}\text { Penjualan Kredit } \\
(\mathbf{X 2})\end{array}$ & Total Pendapatan (Y) \\
\hline 2010 & 99.045 .943 & 4.853 .251 .177 & 4.677 .861 .371 \\
\hline 2011 & 124.032 .164 & 6.077 .576 .030 & 6.195 .045 .835 \\
\hline 2012 & 148.455 .374 & 7.274 .313 .309 & 8.434 .702 .322 \\
\hline 2013 & 181.941 .649 & 8.915 .140 .770 & 7.561 .136 .091 \\
\hline 2014 & 227.113 .942 & 11.128 .583 .153 & 9.605 .497 .475 \\
\hline 2015 & 243.704 .683 & 11.941 .529 .487 & 10.777 .395 .786 \\
\hline Total & $\mathbf{1 . 0 2 4 . 2 9 3 . 7 5 5}$ & $\mathbf{5 0 . 1 9 0 . 3 9 3 . 9 2 6}$ & $\mathbf{4 7 . 2 5 1 . 6 3 8 . 8 8 0}$ \\
\hline
\end{tabular}

Sumber : PT. Traktor Nusantara Cabang Makassar

Pada tahun 2010 hasil penjualan Tunai suku cadang alat berat sebesar Rp. 99.045 .943 dan hasil penjualan kredit sebsar Rp.4.853.251.177 sehinggah dapat diperoleh pendapatan dari hasil penjualan tunai dan penjualan kredit sebesar Rp.4.677.861.371. Pada tahun 2011 hasil penjulan Tunai suku cadang alat berat mengalami peningkatan sebesar Rp.124.032.164 dan penjualan kredit sebesar Rp.6.077.576.030 sehinggah dapat diperoleh pendapatan dari hasil penjualan tunai dan penjualan kredit sebesar Rp.6.195.045.835. Kemudian pada tahun 2012 hasil penjualan tunai suku cadang alat berat sebesar Rp.148.455.374 dan hasil penjualan kredit sebesar Rp.7.274.313.309 sehingga dapat diperoleh hasil pendapatan sebesar Rp.8.434.702.322. Pada tahun 2013 hasil penjualan tunai suku cadang alat berat sebesar Rp.181.941.649 dan hasil penjualan kredit sebesar Rp.8.915.140.770 sehingga dapat diperoleh hasil pendapatan sebesar Rp.7.561.136.091, dimana pada tahun 2013 tingkat pendapatan pada perusahaan PT. Traktor Nusantara Cabang Makassar mengalami penurunan dari tahun-tahun sebelumnya. Pada tahun 2014 hasil penjualan tunai suku cadang alat berat sebesar Rp.227.113.942 dan hasil penjualan kredit sebesar Rp.11.128.583.153 sehingga dapat diperoleh total hasil pendapatan sebesar Rp.9.605.497.475. Kemudian pada tahun 2015 hasil penjualan tunai suku cadang alat berat sebesar Rp.243.704.683 dan hasil penjualan kredit sebesar Rp.11.941.529.487 sehingga dapat diperoleh hasil pendapatan sebesar Rp.10.777.395.786 dan total penjualan tunai selama 6 tahun sebesar Rp.1.024.293.755 sedangkan penjualan kredit sebesar Rp. 50.190.393.926 dan pendapatan Rp.47.251.638.880. 
90|Ad'ministrare, Vol. 3 No. 2, 2016

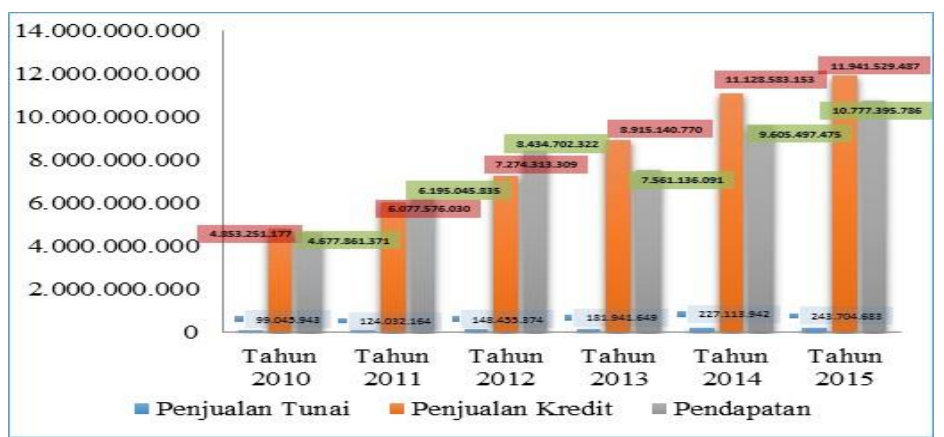

Sumber: PT. Traktor Nusantara Cabang Makassar

\section{Gambar 1 Hasil Penjualan dan Pendapatan}

Pada Gambar 1 terlihat bahwa hasil penjualan tunai suku cadang alat berat mulai tahun 2010 sampai 2015 mengalami peningkatan. Hal ini disebabkan karena keinginan customer yang ingin membeli atau mengganti alat suku cadang yang sudah rusak pada bagian mobil traktor atau peralatan lainnya yang sudah dibeli sebelumnya. Pada penjualan kredit terlihat bahwa lebih besar keingan customer untuk membeli secara kredit dibanding membeli secara tunai. Hal ini disebabkan karena pembelian secara kredit dapat ditunda dalam jangka waktu yang telah ditentukan, sedangkan peda tingkat pendapatan pada perusahaan PT. Traktor Nusantara Cabang Makassar mulai tahun 2010 sampai 2012 mengalami peningkatan dan pada tahun 2013 mengalami penurunan, pada tahun 2014 sampai 2015 kembali mengalami peningkatan.

\section{Uji Hipotesis}

Pengujian hipotesis yang dilakukan pada penelitian ini bertujuan untuk melihat bagaimana pengaruh variabel independen terhadap pengaruh dependen. Pengujian hipotesis ini terdiri atas uji hipotesis secara Parsial dan uji hipotesis secara simultan.

\section{Uji F}

Untuk mengetahui ada tidaknya pengaruh variabel bebas secara keseluruhan terhadap variabel terikat, maka digunakan uji F (Sugiyono,2000: 87).

Hipotesis dalam pengujian ini adalah sebagai berikut:

$$
\mathrm{Ha}=\mathrm{b} 1=\mathrm{b} 2 \ldots \mathrm{bi}=0
$$

Artinya variabel-variabel bebas tidak berpengaruh signifikan terhadap variable Terikat.

$$
\mathrm{Ha} \neq \mathrm{b} 1 \neq \mathrm{b} 2 \neq \ldots \text { bi } \neq 0
$$

Artinya ada pengaruh terhadap variabel terikat, paling tidak ada salah satu dari variabel bebas tersebut. Ketentuan dari penerimaan dan penolakan hipotesis adalah sebagai berikut:

Jika $\mathrm{F}_{\text {hitung }}>\mathrm{F}_{\text {tabel }}$ : Ho ditolak

Artinya variabel-variabel bebas mempunyai pengaruh terhadap variabel terikat.

Jika $\mathrm{F}_{\text {hitung }}<\mathrm{F}_{\text {tabel }}$ : Ho diterima

Artinya variabel-variabel bebas tidak mempunyai pengaruh terhadap variabel terikat. 
Dengan tingkat signifikan 0.05 sehingga apabilah probabilitas dimana apabilah P. value $(\mathrm{sig})<0.05(P<0.05)$ berarti Ho ditolak dengan demikian terdapat pengaruh yang signifikan antara dua variabel bebas atau lebih secara bersama-sama (simultan) dengan variabel terikat.

\section{Tabel 2 Uji F (Simultan)}

\begin{tabular}{|l|r|c|c|}
\hline Model & df & F & Sig. \\
\hline Regression & 2 & 70,533 &, $003^{\mathrm{b}}$ \\
Residual & 3 & & \\
Total & 5 & & \\
\hline
\end{tabular}

a. Dependent Variable: Pendapatan

b. Predictors: (Constant), Penjualan Kredit, Penjualan Tunai

Sumber: Output data SPSS 22, 2016

Berdasarkan hasil perhitungan SPSS 22 dapat diketahui bahwa secara bersama-sama (simultan), Variabel independent atau variabel X1 (penjualan Tunai) dan X2 (penjualan kredit) memiliki pengaruh yang signifikan terhadap variabel dependen $\mathrm{Y}$ (Tingkat Pendapatan). Hal ni dapat dibuktikan dari nilai signifikan sebesar 0,003 nilai $F_{\text {hitung }}$ sebesar 70,533 sedangkan $F_{\text {tabel }}$ pada taraf signifikan 5\% sebesar 9,55 sehingga dari hasil perhitungan bahwa $\mathrm{F}_{\text {hitung }}$ lebih besar dari $F_{\text {tabel }}(70,533>9,55)$ dan nilai signifikansi lebih kecil dari 0,05 Ho ditolak dan Ha diterima artinya variabel bebas mempunyai pengaruh signifikan terhadap variabel terikat. Sehingga dapat disimpulkan bahwa Variabel (X1) penjualan tunai dan (X2) penjualan kredit secara simultan berpengaruh signifikan terhadap peningkatan pendapatan pada perusahaan PT Traktor Nusantara Cabang Makassar.

\section{Uji t ( Uji Persial)}

Uji t dimaksudkan untuk melihat signifikansi dari pengaruh variabel bebas secara parsial terhadap variabel terikat, dengan asumsi variabel bebas lainnya konstan (dalam regresi berganda). Hipotesis dalam pengujian ini adalah sebagai berikut:

Ho: $\mathrm{bi}=0$

Artinya variabel bebas tidak berpengaruh terhadap variabel terikat.

Ho: $b i \neq 0$

Artinya variabel bebas berpengaruh terhadap variabel terikat

Ketentuan penerimaan atau penolakan hipotesis Ho adalah sebagai berikut:
$\mathrm{T}_{\text {Hitung }}>\mathrm{t}_{\text {tabel }}=$ Ho ditolak
P. value $<\propto=5 \%=$ Ho ditolak
$\mathrm{T}_{\text {hitung }}<\mathrm{t}_{\text {tabel }}=$ Ho diterima
Atau
P. value $\geq \propto=5 \%=$ Ho diterima 
Penolakan Ho berarti bahwa dengan tingkat kepercayaan tertentu (5\%) variabel bebas yang diuji secara nyata berpengaruh terhadap variabel terikat dan sebalikya jika Ho diterima berarti variabel bebas yang diuji secara nyata tidak berpengaruh signifikan terhadap variabel terikat. Berdasarkan tabel 3 dengan menggunakan program SPSS 22 dapat dilihat nilai signifikan untuk variabel Penjualan Tunai (X1) sebesar 0,034 dan nilai thitung diperoleh sebesar 3,722 kemudian Variabel Penjualan Kredit (X2) memiliki nilai signifikan sebesar 0,029 dan nilai $t_{\text {hitung }}$ diperoleh sebesar 3,956 sedangkan $\mathrm{T}_{\text {tabel }}$ pada taraf signifikan 5\% sebesar 2,015.

\section{Tabel 3. Uji T (Persial)}

\section{Coefficients $^{\mathbf{a}}$}

\begin{tabular}{|c|c|c|c|c|c|c|c|c|}
\hline \multirow[b]{2}{*}{ Model } & \multicolumn{2}{|c|}{ Unstandardized Coefficients } & \multirow{2}{*}{$\begin{array}{l}\mathrm{SC} \\
\text { Beta }\end{array}$} & \multirow[b]{2}{*}{$\mathrm{t}$} & \multirow[b]{2}{*}{ Sig. } & \multicolumn{3}{|c|}{ Correlations } \\
\hline & B & Std. Error & & & & $\begin{array}{l}\text { Zero- } \\
\text { order }\end{array}$ & Partial & Part \\
\hline (Constant) & 205292474,303 & 694697935,707 & & 296 &, 787 & & & \\
\hline $\begin{array}{l}\text { Penjualan } \\
\text { Tunai }\end{array}$ & $-573,371$ & 154,068 & $-14,890$ & 3,72 &, 034 & ,933 &,- 907 &,- 310 \\
\hline $\begin{array}{l}\text { Penjualan } \\
\text { Kredit }\end{array}$ & 12,561 & 3,176 & 15,826 & $\begin{array}{r}3,95 \\
6\end{array}$ & ,029 & ,940 & ,916 &, 330 \\
\hline
\end{tabular}

Sumber : Output data SPSS 22,2016

Berdasarkan tabel diatas dengan menggunakan program SPSS 22 dapat dilihat nilai signifikan untuk variabel Penjualan Tunai (X1) sebesar 0,034 dan nilai thitung diperoleh sebesar 3,722 kemudian Variabel Penjualan Kredit (X2) memiliki nilai signifikan sebesar 0,029 dan nilai $t_{\text {hitung }}$ diperoleh sebesar 3,956 sedangkan $T_{\text {tabel }}$ pada taraf signifikan 5\% sebesar 2,015. Nilai signifikan untuk variabel (X1) diperoleh 0,034 dan nilai $t_{\text {hitung }}$ Penjualan tunai $-3,722$ dibandingkan dengan $t_{\text {tabel }}$ sebesar 2,015 dari data tersebut tampak bahwa $t_{\text {hitung }}$ lebih besar dari $t_{\text {tabel }}\left(t_{\text {hitung }}>t_{\text {tabel }}\right)$ artinya Ho ditolak dimana variabel bebas atau penjualan tunai berpengaruh terhadap variabel terikat atau tingkat pendapatan. Dan nilai (signifikansi) $=0,034$ lebih kecil di banding $0,05(0,034>0,05)$ maka Ho ditolak berarti variabel bebas yang diuji secara nyata berpengaruh signifikan terhadap variabel terikat.

Maka Dapat disimpulkan bahwa penjualan tunai berpengaruh signifikan terhadap peningkatan pendapatan pada perusahaan PT. Traktor Nusantara cabang Makassar. Nilai signifikan untuk variabel (X2) diperoleh 0,029 dan nilai thitung Penjualan kredit 3,956 dibandingkan dengan $t_{\text {tabel }}$ sebesar 2,015 dari data tersebut tampak bahwa $t_{\text {hitung }}$ lebih besar dari $t_{\text {tabel }}\left(t_{\text {hitung }}>t_{\text {tabel }}\right)$ artinya Ho ditolak dimana variabel bebas atau penjualan kredit mempunyai pengaruh terhadap variabel terikat atau tingkat pendapatan. Dan tingkat signifikan pada penjualan kredit adalah 0,029 lebih kecil di banding 0,05 $(0,046<0,05)$ maka Ho ditolak berarti variabel bebas yang diuji secara nyata berpengaruh signifikan terhadap variabel terikat. Maka Dapat disimpulkan bahwa penjualan kredit berpengaruh signifikan terhadap peningkatan pendapatan pada perusahaan PT. Traktor Nusantara cabang Makassar. 


\section{Persamaan Regresi}

Analisis regresi linear berganda adalah hubungan secara linear antara dua atau lebih variabel independen $(\mathrm{X} 1, \mathrm{X} 2 . . \mathrm{Xn})$ dengan variabel dependen $(\mathrm{Y})$. Analisis ini untuk mengetahui arah hubungan arah hubungan antara variabel independen dengan variabel dependen apakah masing-masing variabel independen berhubungan positif atau negatif dan untuk memprediksi nilai dari variabel dependen apabila nilai variabel independen mengalami kenaikan atau penurunan.

\section{Tabel 4 Koefisien determinasi}

Model Summary ${ }^{b}$

\begin{tabular}{|c|c|c|c|c|c|c|c|c|c|}
\hline \multirow[b]{2}{*}{ Model } & \multirow[b]{2}{*}{$\mathrm{R}$} & \multirow[b]{2}{*}{$\begin{array}{c}\mathrm{R} \\
\text { Square }\end{array}$} & \multirow[b]{2}{*}{$\begin{array}{c}\text { Adjusted R } \\
\text { Square }\end{array}$} & \multicolumn{5}{|c|}{ Change Statistics } & \multirow[b]{2}{*}{ Durbin-Watson } \\
\hline & & & & $\begin{array}{c}\mathrm{R} \\
\text { Square } \\
\text { Change } \\
\end{array}$ & $\begin{array}{c}\mathrm{F} \\
\text { Change } \\
\end{array}$ & $\begin{array}{c}\mathrm{df} \\
1 \\
\end{array}$ & df2 & $\begin{array}{c}\text { Sig. F } \\
\text { Change }\end{array}$ & \\
\hline 1 &, $990^{\mathrm{a}}$ & ,979 & 965 & ,979 & 70,533 & 2 & 3 & ,003 & 2,768 \\
\hline
\end{tabular}

Persamaan regresi linear berganda sebagai berikut:

$$
\mathrm{Y}=\mathrm{a}+\mathrm{bX}+\mathrm{bX}+\mathrm{E}
$$

$$
\mathrm{Y}=205292474,303-573,371+12,561+\mathrm{E}
$$

Dimana pada variabel $\left(\mathrm{X}_{1}\right)-573,371$ yang merupakan koefisien regresi pada variabel $X_{1}$. Nilai tersebut menunjukkan besar pengaruh variabel $X_{1}$ terhadap variabel terikat dan tanda negatif menunjukkan bahwa variabel $\mathrm{X}_{1}$ memberikan kontribusi negatif artinya setiap kenaikan satu satuan pendapatan tunai itu akan mengurangi pendapatan sebesar $-573,371$. Dimana pada variabel $\left(\mathrm{X}_{2}\right)$ 12,561 yang merupakan koefisien regresi pada variabel $\mathrm{X}_{2}$. Nilai tersebut menunjukkan besar pengaruh variabel $\mathrm{X}_{2}$ terhadap variabel terikat dan tanda positif menunjukkan bahwa variabel $\mathrm{X}_{2}$ memberikan kontribusi positif artinya setiap kenaikan satu satuan pendapatan kredit itu akan menambah pendapatan sebesar 12,561.

\section{Koefisien Determinasi $\left(\mathbf{R}^{2}\right)$}

Koefisien Determinasi digunakan untuk mengetahui seberapa besar pengaruh variabelvariabel bebas memiliki pengaruh terhadap variabel terikatnya. Nilai koefisien determinasi untuk variabel bebas lebih dari dua digunakan Adjusted R Square yaitu:Dari hasil perhitungan dengan menggunakan rogram SPSS 22 dapat diketahui bahwa koefisien determinasi sebesar 0,965 hal ini berarti $96,5 \%$ pendapatan dapat di jelaskan oleh variabel penjualan tunai dan penjualan kredit, sedangkan sisanya yaitu 3,5\% pendapatan dipengaruhi oleh variabel-variabel lainnya yang tidak di teliti dalam penelitian ini. 
94|Ad'ministrare, Vol. 3 No. 2, 2016

\section{SIMPULAN}

Berdasarkan uji $\mathrm{F}$ dan uji $\mathrm{t}$ didapatkan hasil bahwa penjualan tunai suku cadang alat berat berpengaruh signifikan terhadap peningkatan pendapatan PT. Traktor Nusantara cabang makassar tetapi tidak signifikan. Hal ini dapat di buktikan dari nilai signifikan uji t pada penjualan tunai 0,034 lebih besar di banding $0,05(0,034<0,05)$ maka Ho ditolak berarti variabel bebas yang diuji secara nyata berpengaruh signifikan terhadap variabel terikat.

\section{DAFTAR PUSTAKA}

Dendawijaya dan Lukman. 2003. Manajemen Perbankan, Penerbit Ghalia Indonesia. Jakarta.

Deddy Nurdiawan.2009, Akuntansi Pemerintahan,salemba empat jakarta

Eugene F, 2001, Manajemen Keuangan, edisi kedelapan, Erlangga jakarta

Kieso, weygandt dan warfield. 2007, Akuntansi Intermedia, edisi kedua belas,jilid 2, erlangga Jakarta

Mulyadi. 2000. Akuntansi Biaya Edisi 5 Yogyakarta: Aditya Media.

Mulyadi. 2001. Sistem Akuntansi. Jakarta: Penerbit Salemba Empat.

Mulyadi. 2001. Sistem Akuntansi Edisi 3. Bagian Penerbitan Salemba Empat. Jakarta.

Suhardjono. 2003. Manajemen Perkredita usaha kecil dan menengah. Yogyakarta: (UPP) AMP YKPN.

Mulyono,TP, 2007. Manajemen Perkreditan Bagi Perbankan Komersil. Yogyakarta: BPFE.

Ahmad, Komaruddin. 2004. Dasar-Dasar Manajemen Investasi dan Portofolio. Edisi Revisi. Jakarta: PT. Rineka Cipta.

Bambang Riyanto. 1990. Dasar-dasar Pembelanjaan. Yayasan Badan Penerbit Gajah Mada. 